\title{
世界結晶年 (IYCr2014）＼cjkstart対称性・群論トレーニングコース
}

総合科学研究機構 岡㟝伸生

\begin{abstract}
Nobuo OKAZAKI: Experience Note of the Traning Course on Symmetry and Group Theory, Tsukuba 2014
\end{abstract}

\section{1. はじめに}

2014 年 8 月 14 日〜 17 日の日程で, 高エネルギー加速器 研究機構つくばキャンパス研究本館において開催された 『世界結晶年 (IYCr2014) 対称性・群論トレーニングコー ス』に参加する機会を得た. 本コースは, 群論について体 系的な講義を受けることができる，(抢そらく）日本では 数少ない機会ということもあり, JPXTALメーリングリス 卜に告知が流れてから 1 週間ほどで 30 名程度の参加枠が 埋まってしまうほどの人気だったようである. 講義はフラ ンス・ロレーヌ大学結晶学教室の Masshimo Nespolo教 授により日本語で行われた.プレ講義として代数学から始 まり, 最終的に空間群, 消滅則, 部分群などに到達する内 容であった。

私は 10 年ほどタンパク質結晶構造解析にかかわる研 究・開発を行っていたため, 今回の講義内容は「知ってい て当然」であるべきなのだが，実際は「何となく聞いたこ とがあるけど・.よく知らない」という恥ずかしいレベルで あるということをまず断って拉きたい，そのため，申し込 む際も「果たして講義についていけるのだろうか」という のが一番の心配事であったのだが, 果たしてその結果, 理 解が進んだのかどうかは本文を読んで判断していただき たいと思う。

\section{2. トレーニングコース概要}

\section{1 プレ講義 $8 / 14$ (木)}

群論の講義に先だって, 代数学の講義が半日開講され た. 行列の演算に始まり, 跡や行列式の求め方, 余因子行 列や拡大行列というように続いた. 行列の演算はともか く,その他の内容は高校や学部時代の講義で習った内容た と思われるが, 言葉が何となく頭に残っている程度だった ため, すでに初日（といっても4時間ほど) から頭の中は 知恵熱状態であった. 次の日からは本格的な講義になると のことで, 早くも不安でいっぱいのスタートを切った.

\section{2 講義 1 日目 $8 / 15$ (金)}

お盆まっただ中の夏の日, プログラムを見ると講義予定 時間が9時〜 19 時と書かれているのがさらなる不安をあ おる。この日は抽象代数学入門から始まる内容であった。 内容は『抽象』の名のと抢り, 完全に抽象的な代数的な構 造の話となり，いきなり(私には) ハイレベルな内容— マグマ, 準群, 半群, ループ, モノイド, 群, アベール群,

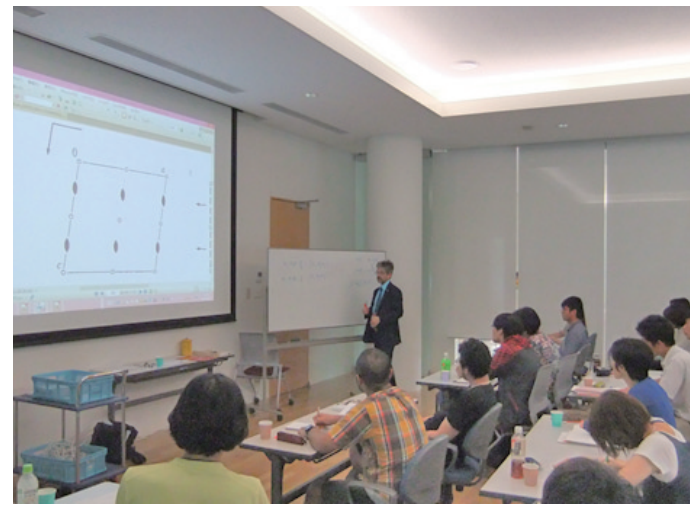

講義風景

圈, 亜群…一であり, 早々に先の見えないトンネルに足 を踏み入れたような感覚の中にいた (不甲斐なくて申し訳 ない). その後, 結合律, 単位元…などと話は進み, 点群に たどり着いた，本講義は『演習を適宜行いながら』とされ ており, セクションごとに基礎的, 応用的な例題を行いつ つ進められた. そのため, 上記のような馴染みのない言葉 や内容が出てきても演習を行うことで理解が少しずつ進 んだよに思う。もし演習がなかったら何のことやら，の まま講義が進んでいったかもしれず, これは大変有効な方 法であった.さらにこの後内容は進み, 19 時頃に講義 1 日 目は終了し, 懇親会が開かれた。

\section{3 懇親会}

本コースは 30 人程度の小さな集まりのため, 乾杯の後, 一人ずつ簡単な自己紹介が行われた. コース終了の数日後 に大学院入試を控えている学部 4 回生 (その後, 試験は無 事に乗り越えられたのだろうか), タンパク質結晶構造の 博士課程の学生, $\mathrm{X}$ 線結晶構造解析の講義を受けもつこと になったので復習のため‥といったさまざまな分野, 立場 の方々が, 大半は大学関係, 残りが公的研究機関から参加 していた. 自分の学生時代を顧みるに, このようなコース にしっかり参加する学生には頭が下がる思いである. 通常 の学会と異なり, ほとんどの人が初対面であり, 懇親会の 始まりは少々ぎこちない感じがあったが, そこは研究者同 士であり, 分野や研究内容をお互い話したりして次第に盛 り上がっていたように思う.ややがて会場を閉めるというの で, 場はドミトリーへ. 今回のように, 大半が同じ宿舎と いうのはエンドレスな宴会になるキケンをはらんでおり, 次の日も内容も時間割もハードな講義があるのがわかっ ていながら, 結局日付が変わるまで数人の参加者と歓談す 
ることになってしまった‥(楽しかったのだけど).

\section{4 講義 2 日目 $8 / 16$ (土)}

寝不足で迎えた講義 2 日目. こんな状態で講義について いけるのだろうかと心配だったが, 少しの救いは，この日 から対称操作などの内容が始まったこと.未熟者とはい え，ある程度は結晶構造解析にかかわってきたため，己れ までの抽象的な内容に比べると馴染みのある内容であっ た. 二次元の晶ファミリーとブラベ格子から始まり，その 基礎を学んだ後, 三次元へと拡張する, といった内容であ った. その後, 対称操作に進み, International Tables で馴 染み深い格子点の演習を行った. ただ, 私の専門分野は夕 ンパク質結晶であり, 鏡映操作を含む対称操作には馴染み がなかったため今さらながらではあるが新鮮であった。 そ んなこんなで 2 日目の講義が終了した.この日の夜はカレ 一が用意され，おいしかったのである。

\section{5 講義 3 日目 $8 / 17$ (日)}

ハードな日々を乗り越え，いよいよ最終日．この日は前 日の内容からさらに実践的 (?) と言える消滅則から始ま った. 消滅則などは結晶構造解析を行っている人間にとっ ては基礎の基礎であるが, 消滅則についての講義を聴きな

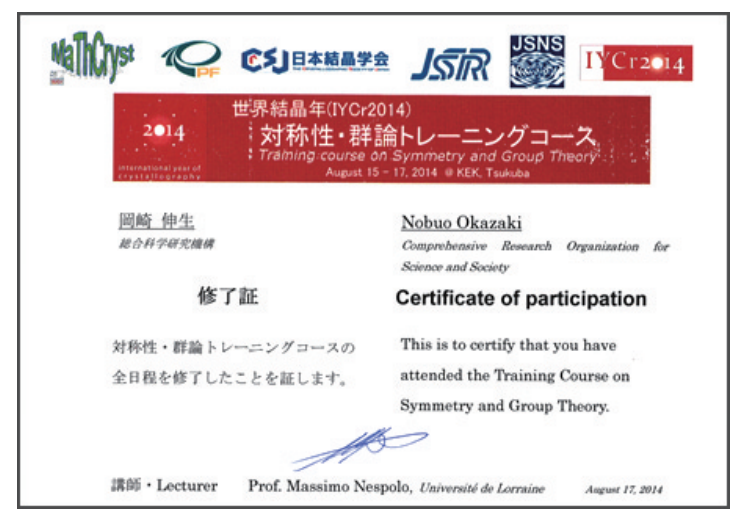

栄誉の『修了証』
がら「おー,そうだったのか！」とこの歳になってようや く納得していたのは秘密である。このように, これまでは 「何となく」「そういうものた」という状態で停止してい

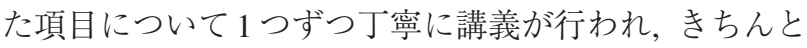
理屈で整理されてきた，たた，さすがにここまで来ると 整理されても収納する余力がなく，教授には申し訳な いことに, 体力, 思考能力ともに限界を迎えて最終日の 講義が終了した.

\section{3. 講義を受けて}

本講義は内容の高度さもさることながら, 密度も高く, かなりハードな 3 日間 (十半日) であった。具体的には 9 時に講義が始まり, 10 時半頃にCoffee Break, 11 時再開 で 12 時半頃にランチとなる. 午後の講義は 14 時から始 まり(すこし海外っぽい?), 16 時半頃に休㮩, 最後に 17 時から 19 時で終了. おおまかにはこのようなスケジュー ルであった。これだけ長時間連続で講義を受けることは 20 年近く前の学部時代以来であり, 講義が終わった頃に はクタクタになっていた。狯議が始まれば寝てしまう体 質』と日頃自認している私であるが, 本講義では意識が飛 ぶことが(ほとんど) なく，何とかついていけた（ような 気がした) のは, Nespolo 教授の講義内容の構成, 教え方が あってこそだったのかもしれない.今回残念ながら参加で きなかった方々も含め, 多くの人たちが参加できるよう に, 今後もこのような企画が定期的に行われることを希望 したい. 末筆ながら，4 日間にわたり素晴らしい講義を行 っていただいたNespolo 教授はもちろん, 企画を実行し ていただいた実行委員の KEK 五十嵐博士, 東工大 奥部博 士，KEK 神山博士ならびに事務局の KEK 高橋氏，関係 者の方々に深く感謝し, 一緒に講義を受けた方々の今後ま すますの活躍を期待しつつ，この夏の報告としたい。

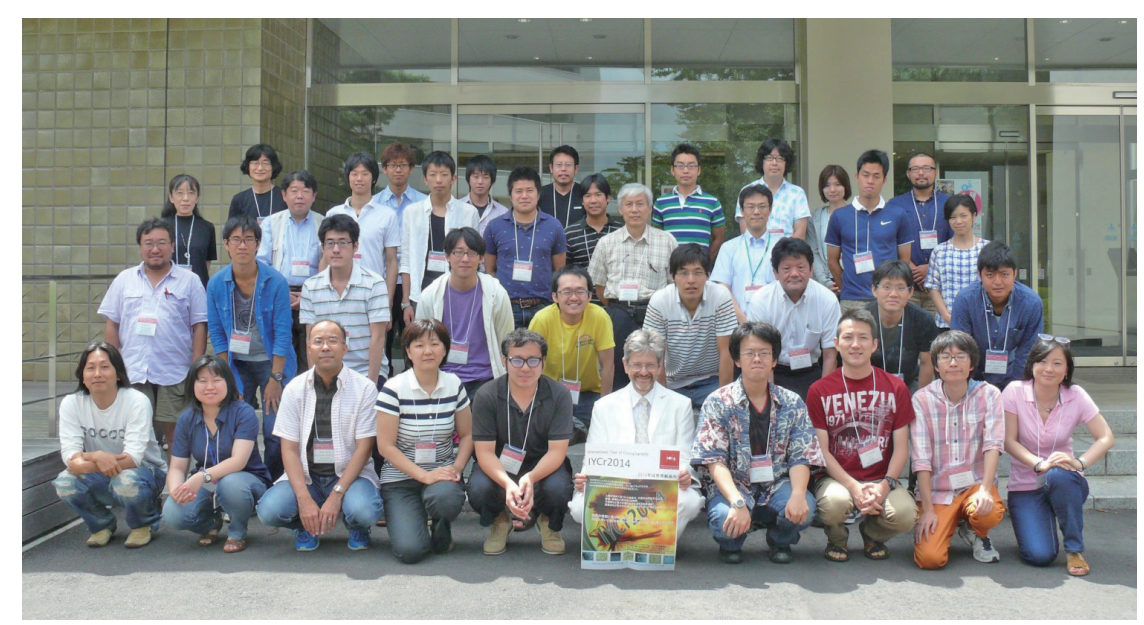

ありがとうございました！ 